\title{
National Survey on Terrapins and Tortoises of Sri Lanka: Current Status of Terrapins in Six Districts, with Future Prospects
}

\author{
D.M.S.S. Karunarathna ${ }^{1}$, W.M.S. Botejue ${ }^{2 *}$, D.E. Gabadage ${ }^{3}$ \\ ${ }^{1}$ Nature Explorations and Education Team, Moratuwa 10400, Sri Lanka \\ ${ }^{2}$ Biodiversity Conservation Society, Nugegoda 10250, Sri Lanka \\ *madhavabotejue@gmail.com
}

\begin{abstract}
The terrapins and tortoises consist of over 330 species around the world, and are the most threatened reptiles. Sri Lanka is home to three species and two sub-species. One species and the two sub-species appear to form an endemic radiation: Lissemys ceylonensis, Melanochelys trijuga parkeri, Melanochelys trijuga thermalis, Geochelone elegans is widely spread throughout the South Asia. Trachemys scripta is considered as an alien invasive species. A national survey is currently under way regarding the diversity, population, distribution and conservation of these species and this study is a part of the said survey and only focused on L. ceylonensis and M. trijuga thermalis in six districts.

A field survey was carried out from November 2014 to April 2015 along aquatic habitats in Colombo, Galle, Gampaha, Hambantota, Kalutara and Matara Districts using $79\left(200 \times 20 \mathrm{~m}^{2}\right)$ transects. Number of transacts conducted at each district were 18 in Colombo, 16 in Galle, 17 in Gampaha, 8 in Hambantota, 10 in Kalutara, 10 in Matara. Data was also collected from fisherman, villagers, tourists and vehicle drivers (regarding road kills) through interviews and questionairs. Comments from 183 individuals were also recorded. Behaviours of some captive individuals were also observed.
\end{abstract}

A total of 103 terrapins (39[60\%] adults, 26[38\%] sub-adults and 3[5\%] juveniles) were recorded naturally, including 68(66\%) (39[54.4\%] adults, 26[38.2\%] sub adults and 3[4.4\%] juveniles). L. ceylonensis and 35[34\%) (21[60\%] adults, 12[34.3\%] sub-adults and 2[5.7\%] juveniles) $M$. trijuga thermalis.

Even though these species are not considered as threatened, their habitat degradation is at an alarming rate and the highest abundance of these species are distributed outside of protected areas. They are also threatened by hunting and illegal pet trade. The entire native species were described about 75 years back and no proper survey have been carried out to estimate the abundance and to recognising the threats. Therefore, it is essential and a matter of urgency to carry out a proper island wide survey to establish an accurate conservation status for these species. Based on the survey results, suitable conservation action plans and policies should be fashioned.

Keywords: Diversity, Population, Distribution, Conservation, Management policies, Action plans 